MISES: Revista Interdisciplinar de Filosofia, Direito e Economia

ISSN 2318-0811

Volume IV, Número 1 (Edição 7) Janeiro-Junho 2016: 209-223

\title{
Justiça Social no Pensamento de Friedrich Hayek - Parte I*
}

\author{
Patrick Coelho Campos Gappo**
}

\begin{abstract}
Resumo: Discute-se a questão da justiça social no pensamento de Friedrich A. Hayek, começando por um panorama do pensamento liberal, buscando demonstrar como o autor se insere nesse contexto intelectual. Em seguida, apresentamos os principais conceitos da filosofia política de Hayek e finalmente usamos essa base para discutir a negação que o pensador austríaco faz sobre o conceito de justiça social. Concluímos com algumas reflexões sobre os temas abordados e a ordem de mercado.
\end{abstract}

Palavras-Chave: Liberalismo. Friedrich Hayek. Justiça social. Teoria da justiça. Liberdade. História do liberalismo. Ordem de mercado.

\section{Social Justice in Friedrich Hayek's Thought}

\begin{abstract}
We discuss the question of social justice in Friedrich Hayek's thought, beginning with a panorama of liberal thought, trying to show how the author inserts in it. Afterwards, we present the main concepts of Hayek's political philosophy and finally we use this basis to discuss how he denies the concept of social justice. We conclude with some reflections about the subjects discussed and the issue of market order.
\end{abstract}

Keywords: Liberalism. Friedrich Hayek. Social justice. Theory of justice. Liberty. History of liberalism. Market order.

Classificação JEL: B53, K10.

\footnotetext{
"A segunda parte deste artigo será publicada na próxima edição do periódico MISES: Revista Interdisciplinar de Filosofia, Direito e Economia.

"* Patrick Coelho Campos Gappo é graduado em Direito pela Universidade do Estado do Rio de Janeiro (UERJ). E-mail: patrickgappo@msn.com
} 


\section{I - INTRODUÇÃo}

Ao introduzir o livro Fundamentos da Liberdade, Friedrich A. Hayek (1899-1992) faz a observação de que os ideais da liberdade que possibilitaram a moderna civilização ocidental estão sem defesa atual ${ }^{1}$. Entende que os princípios básicos sobre os quais está fundamentada a sociedade vêm caindo no esquecimento enquanto os cientistas sociais buscam criar ordens sociais alternativas. Ao mesmo tempo, na academia, o pensador austríaco vê a falta de uma obra que apresente um quadro completo da filosofia na qual uma teoria liberal possa se fundamentar ${ }^{2}$.

A burguesia tinha em mente a ideia de liberdade, que implica a ideia de competição. Se há liberdade, cada um chega até aonde pode. Se alguém diz isso hoje, parece oligarca. Mas no seu momento a ideia de liberdade foi revolucionária: que cada um chegara até onde pudera e não até onde seu nascimento o tinha predestinado, era uma proposição inovadora, audaz no século XVIII ${ }^{3}$.

Nos últimos anos, vemos um crescimento do interesse de trabalhos acadêmicos nas obras e no pensamento de Hayek. Tal interesse pode ter sido influenciado pelas visitas que o pensador fez ao Brasil entre 1977 e 1981. Assim, citamos um trecho desse livro que comenta sobre a importância do seu pensamento.

Poucos homens, se é que há algum, contribuíram tanto quanto Hayek para as ciências sociais. Seguramente nenhum neste século colocou de forma tão firme, segura e convincente a filosofia da liberdade do homem, da liberdade do homem como indivíduo em contraposição à filosofia da liberdade coleti-

\footnotetext{
${ }^{1}$ A publicação original da obra foi em 1959 nos EUA.

${ }^{2}$ HAYEK, Friedrich August von. Os Fundamentos da Liberdade. Tradução de Anna Maria Capovilla e José Ítalo Stelle. São Paulo: Visão, 1983. p. XXXIII.

${ }^{3}$ GRONDONA, Mariano. Os Pensadores da Liberdade: de John Locke a Robert Nozick. Trad. Ubiratan de Macedo. São Paulo: Editora Mandarim, 2000. p. 87.
}

va, onde o indivíduo é mero adesista, a despeito da fachada humanística e democrática da filosofia coletivista ${ }^{4}$.

Hayek é um autor que ultrapassa divisões políticas e partidárias. Sua contribuição para as mais diversas áreas do pensamento é estudada por todo o espectro ideológico. Neste sentido, citamos aqui um comentário do Cambridge Companion to Hayek sobre a reação do economista austríaco ao saber da grande receptividade de $O$ caminho da servidão pela direita inglesa.

Tudo isso [a grande receptividade do livro pela 'direita'] deve ter sido particularmente difícil para Hayek, porque ele havia sido inicialmente levado à economia pelo desejo de melhorar a condição social das pessoas, e ele era um socialista fabiano moderado quando jovem. Mesmo depois de publicar o caminho da servidão, Hayek numa palestra para alunos da LSE deixou claro que ainda tinha simpatia emocional por alguns ideais socialistas $^{5}$.

O objetivo deste trabalho é, considerando a importância do pensamento de Hayek, fazer um panorama de seus trabalhos e adentrar na discussão de teoria da justiça, com foco na sua negação da justiça social.

Trabalharemos Hayek com foco em dois de seus livros, Fundamentos da Liberdade e Direito, Legislação e Liberdade. Hayek é um autor com extensa bibliografia, por isso escolhemos nos concentrar nestes dois livros, uma vez que tratam mais especificamente da questão de teoria da justiça e justiça social. Estamos cientes de que Hayek em algumas obras e nestas duas que indicamos faz uma proposta de construção de instituições políticas que alguns consideram socialdemocrata. Por não ser o foco deste trabalho preferimos não abordá-la.

\footnotetext{
${ }^{4}$ PRUNES, Cândido Mendes (org.). Hayek no Brasil. Rio de Janeiro: Instituto Liberal, 2006. p.54

${ }^{5}$ FESER, Edward (org.). The Cambridge Companion to Hayek. Cambridge: University Press, 2006. p.154.
} 
Pode parecer que demoramos até chegar à questão da justiça social e teoria da justiça em Hayek, mas consideramos que o presente ensaio perderia qualidade se não traçasse o caminho aonde se situa Hayek e quais são os elementos que caracterizam sua filosofia política.

\section{II - Breve História do Pensamento LiBERAL}

Hayek, além de suas contribuições para o pensamento liberal, foi um grande sistematizador deste. Dessa forma, não é possível a boa compreensão do seu pensamento sem antes fazer um panorama geral da tradição intelectual liberal, para entender como o austríaco se insere nesta escola.

José Guilherme Merquior (1941-1991) considera difícil definir o liberalismo, pois este é antes de tudo um movimento histórico ${ }^{6}$. Pode-se identificar o liberalismo como visão de mundo, doutrina e movimento político. Enquanto a filosofia política grega foi exposta depois do grande ciclo da política grega, a filosofia moderna foi pensada e desejada antes de ser empregada. Pierre Manent considera que a política liberal é essencialmente deliberada e experimental, fruto de um projeto consciente e construído.

A mais rápida olhadela revela um traço central e singular de nossa situação histórica: o pensamento político e a vida política estão, na época moderna, ligados por um vínculo imediato e íntimo. Isso é inédito. Podemos narrar a história política da Grécia ou de Roma sem a intervenção de ideias ou das doutrinas ${ }^{7}$.

\footnotetext{
${ }^{6}$ MERQUIOR, José Guilherme. O Liberalismo: antigo e moderno. Tradução de Henrique de Araújo Mesquita. São Paulo: É Realizações, 2014. p. 40.
}

${ }^{7}$ MANENT, Pierre. História intelectual do liberalismo: dez lições. Tradução de Vera Ribeiro. Rio de Janeiro: Imago Ed, 1990. p. 7.
Sobre a história do termo, liberal como rótulo político nasceu das Cortes espanholas de 1810 em revolta contra o absolutismo, apesar do liberalismo como fenômeno datar para a maioria dos autores da revolução gloriosa de $1688^{8}$. Nesse contexto, vale lembrar a mudança do conceito de liberalismo nos Estados Unidos da América. Durante a era progressista, o termo passou a ser associado à socialdemocracia e formas de intervenção estatal na economia.

Ubiratan Borges de Macedo (1937-2007) ${ }^{9}$ oferece um bom resumo sobre as teses do liberalismo clássico nos campos filosófico, político, social e econômico.

Filosoficamente o liberalismo defende a distinção entre liberdade negativa e positiva, o humanismo antropocêntrico, o individualismo metodológico, a fé no progresso, a distinção entre público e privado e a distinção entre fatos e valores, natureza e cultura.

As teses políticas são legalidade e direitos humanos, consentimento como base do governo, governo representativo, constitucionalismo que institua um estado limitado de direito, soberania popular apurada em sufrágio universal e partidos políticos como meio de canalizar a vontade política do povo.

No campo social o liberalismo endossa o pluralismo, a tolerância civil, a separação entre Igreja e Estado, a secularização, a abertura dos serviços sociais e a emancipação da mulher.

Entre as teses econômicas estão: (i) a crença no mercado; (ii) a revalorização do trabalho como fonte de dignidade; (iii) a defesa da propriedade privada como estrutura do sistema econômico; (iv) a defesa da livre empresa e iniciativa humana, do lucro como estímulo e medida da economia; (v) a primazia do contrato sobre o estatuto; (vi) e a admissão

\footnotetext{
${ }^{8}$ MERQUIOR. O Liberalismo: antigo e moderno, p.41.

${ }^{9}$ Os itens a seguir estão em MACEDO, Ubiratan Borges de. Liberalismo e Justiça Social. São Paulo: IBRASA, 1995. p. 29.
} 
da intervenção estatal apenas em casos definidos e autorizados por lei, sem substituir o mercado.

\section{II.1 - Diferentes Tradições Liberais}

Consideradas essas como as teses principais do liberalismo, adentremos brevemente nas suas principais correntes. Para Hayek existem duas tradições diferentes de liberdade, a inglesa e a francesa. A primeira parte de bases empíricas e baseia-se na interpretação das tradições e instituições que surgiram de modo espontâneo. A segunda é racionalista e busca construir por tabula rasa uma nova sociedade com o uso da razão. A liberdade francesa é buscada no Estado e assenta-se na organização, enquanto a inglesa tende à evolução. Apesar de ambas estarem agrupadas hoje na categoria do iluminismo apresentam uma visão fundamentalmente distinta da evolução e ao funcionamento de uma ordem social ${ }^{10}$.

Da mesma forma, Ubiratan Borges de Macedo distingue as duas tradições do liberalismo. Coloca na tradição francesa nomes como Voltaire (1694-1778), Jean-Jacques Rousseau (1712-1778), Anne Robert Jacques Turgot (1727-1781), Condorcet (1743-1794), Gracchus Babeauf (1760-1797), Thomas Paine (17371809), Jeremy Bentham (1748-1832), James Mill (1773-1836) e Giuseppe Garibaldi (18071882). Na inglesa enquadra como principais expoentes John Locke (1632-1704), Montesquieu (1689-1755), Adam Smith (1723-1790), Immanuel Kant (1724-1804), Wilhelm von Humboldt (1767-1835), Benjamin Constant (1767-1830), Alexis de Tocqueville (1805-1859) e John Stuart Mill (1806-1873). Para a variante continental, a liberdade se realiza por meio do Estado. Existe hostilidade a partidos políticos e o entusiasmo pela unanimidade. Parte de um racionalismo abstrato e metafísico, que vê a essência da realidade na razão ${ }^{11}$.

\footnotetext{
${ }^{10}$ HAYEK. Os Fundamentos da Liberdade, p.57.

${ }^{11}$ MACEDO. Liberalismo e Justiça Social, p. 26.
}

Merquior, por outro lado, vê três grandes escolas de pensamento liberal. No mesmo sentido de Ubiratan de Macedo e Hayek, vê a fonte da escola inglesa na liberdade negativa e a francesa na liberdade política. A diferença está em acrescentar a terceira escola, a Alemã, com origem em Humboldt. Esta foi marcada pela ideia de formação da personalidade, como registrado na famosa frase "educar para a liberdade, e liberdade para educar". O foco da ideia de liberdade está na cultura e no desdobramento do potencial humano ${ }^{12}$.

A tradição inglesa vê a liberdade na espontaneidade e ausência de coerção, defende a evolução orgânica, lenta e parcialmente consciente, usando um processo experimental. Entende que as instituições, a moral e o direito evoluíram por um processo de crescimento cumulativo, ao longo de gerações. Busca na antiguidade o exemplo de Atenas e Roma.

Segundo Cícero (106 a.C.- 63 a.C.), Catão teria dito que a constituição romana era superior à dos outros Estados, porque 'se baseava não na genialidade de um único homem, mas na genialidade de muitos: ela não foi instituída no espaço de uma única geração, mas elaborada ao longo de vários séculos e muitas gerações ${ }^{13}$.

A tradição francesa acredita que a liberdade se concretiza na busca e realização de um propósito coletivo absoluto, seguindo um padrão obrigatório. Essa escola vê a razão humana como criadora das instituições, e a sociedade civil como tendo sido formada por um primeiro legislador sábio, ou pelas diversas teorias de contrato social originário. $\mathrm{O}$ exemplo da antiguidade que buscam é o de Esparta ${ }^{14}$.

No liberalismo clássico, a liberdade é um valor que só pode ser assegurado por um governo limitado. A escola segue um racionalismo moderado e evolutivo, partindo da tese

\footnotetext{
12 MERQUIOR. O Liberalismo: antigo e moderno, p. 52-58.

${ }^{13}$ HAYEK. Os Fundamentos da Liberdade, p. 59.

${ }^{14}$ Idem. Ibidem, p. 59.
} 
epistemológica de que só se dispõe da razão para conhecer a realidade, ainda que esta possa não se conter nos limites da razão ${ }^{15}$. Outro conceito fundamental dessa escola é a ordem espontânea, em oposição à planejada.

O liberalismo francês tem raízes na escola racionalista, que acredita que o homem foi originalmente dotado dos atributos morais e intelectuais que permitiram moldar a civilização de acordo com o seu projeto. Para Hayek, os liberais franceses têm visões idealizadas como a bondade natural do homem e a harmonia natural de interesses, além de enxergarem o homem como propenso à ação racional e dotado de inteligência e bondade naturais ${ }^{16}$.

Resumindo: a teoria inglesa dizia que a liberdade significava independência. $\mathrm{O}$ conceito francês (de Rousseau) consistia em que a liberdade é autonomia. A escola alemã replicou a isso que a liberdade é realização pessoal. $\mathrm{O}$ ambiente político da teoria francesa residia no princípio democrático; e o da teoria alemã era o Estado 'orgânico', uma mistura de elementos tradicionais e modernizados $^{17}$.

O liberalismo inglês, ligado à escola evolucionista, vê por outro lado a civilização como um resultado cumulativo e conseguido mediante o processo de tentativa e erro. A civilização é a soma das experiências. Os liberais ingleses veem a natureza humana de forma próxima à tradição cristã, ou seja, falível. Por isso, certas estruturas institucionais levariam o homem a utilizar da melhor forma sua inteligência, e as instituições poderiam ser estruturadas para minimizar o mal praticado pelo homem ${ }^{18}$.

\footnotetext{
${ }^{15}$ MACEDO. Liberalismo e Justiça Social, p. 26.

${ }^{16}$ HAYEK. Os Fundamentos da Liberdade, p. 62.

${ }^{17}$ MERQUIOR. O Liberalismo: antigo e moderno, $p$. 58.

${ }^{18}$ HAYEK. Os Fundamentos da Liberdade, p. 62.
}

\section{II.2 - Evolução do pensamento liberal de Locke a Hayek}

Hayek $^{19}$ traça o surgimento da liberdade individual dos nossos dias ao século XVII. Mesmo assim, admite algumas contribuições do mundo clássico e medieval, dizendo que a Atenas clássica e a Roma republicana possuíam liberdade individual, e a idade média nos legou o conceito de lei como algo superior ao Estado e seus governantes. De acordo com a tradição medieval as leis eram descobertas, e não criadas.

A Grécia antiga emprestou o conceito que seria depois popularizado na Inglaterra do século XVII de isonomia, entendido inicialmente não como um controle da política do governo, mas como a certeza de ser governado em consonância com normas conhecidas. Posteriormente na Grécia antiga foi usado como justificativa para a democracia, até tornar-se evidente que ambos os conceitos, embora relacionados, não constituíam a mesma coisa. Aristóteles condenava o sistema em que o povo, e não a lei, governa, além de defender que o juiz deveria ter pouco poder discricionário, uma vez que a decisão do legislador tem caráter geral $^{20}$.

Deveríamos dar um passo a mais e perguntar se não poderíamos incluir Aristóteles como um pensador da liberdade (...) Aristóteles foi interpretado pelas pessoas como lhes convinha, e nos perguntamos agora se em Aristóteles não há uma dimensão compatível com a liberdade. Esse tipo de operação, sem querer responder a uma verdade o objetiva, é muito importante para nós de modo estratégico ${ }^{21}$.

A tradição da república romana, que chegou ao seu apogeu com Cícero, também

\footnotetext{
${ }^{19}$ Idem. Ibidem, p.184.

${ }^{20}$ Idem. Ibidem, p.189.

${ }^{21}$ GRONDONA. Os Pensadores da Liberdade: de John Locke a Robert Nozick, p. 173.
} 
é de isonomia, formação de uma lei consuetudinária e o primeiro sistema de direito privado completamente desenvolvido. Bastante diferente é o código depois elaborado por Justiniano (482-565), que aumentou o controle do Estado sobre a atividade econômica e instituiu a criação de leis. Foi essa última tradição que influenciaria a Europa continental no renascimento ${ }^{22}$. Contrariamente à Europa continental, a tradição de Atenas e da Roma republicana influenciaria a Inglaterra.

Pierre Manent ${ }^{23}$ começa o estudo do surgimento do liberalismo pelo período que o precede, a era das monarquias absolutistas. Seu surgimento é entendido como uma forma de solucionar o problema de organização do mundo leigo numa forma que não fosse nem a cidade e nem o império. A Europa depois do fim do Império Romano tinha como pontos de referência para a organização política tanto a cidade quanto o império, com o desafio de compatibilizar ambos com os problemas levantados pela Igreja, que detinha a universalidade moral. Esse é o chamado problema teológico-político, que Manent considera ser a grande questão de organização política da era moderna.

As cidades sofriam do problema da particularidade frente à universalidade do império e da Igreja. Tinham uma vida política extremamente intensa e a postura natural de seus membros era afirmar sua liberdade e independência. O império, por outro lado, tinha como grande problema o fato de seu lugar, o universal, já estar ocupado pela Igreja. Nesse sentido a monarquia resolve o problema teológico-político da modernidade, pois diferentemente da cidade, o rei poderia aspirar ao direito divino uma vez que cumpria o requisito da unicidade. Além disso, a vida política num reino era mais modesta que numa cidade, deixando os homens livres para se dedicarem às coisas do outro mundo. Finalmente,

\footnotetext{
${ }^{22}$ HAYEK. Os Fundamentos da Liberdade, p. 190.

${ }^{23}$ MANENT. História intelectual do liberalismo: dez lições, p. 15.
}

a postura natural dos súditos de um monarca era a obediência, e diferente do império, este monarca não aspirava à monarquia universal, diminuindo o conflito com a universalidade da Igreja ${ }^{24}$.

A etapa seguinte, que muitos autores tomam como início do liberalismo, são as revoluções inglesas. Para Manent, a guerra civil inglesa causou a urgência da resposta de duas perguntas, uma sobre o sentido da instituição monárquica, e outra sobre o lugar da religião na definição do corpo político ${ }^{25}$.

A reforma protestante na Inglaterra e o direito do monarca determinar a religião dos seus súditos colocou este numa situação vulnerável. Os esforços dos reis para impor um cristianismo balizado pela nobreza não satisfez nem ao conjunto de protestantes nem aos católicos remanescentes. Dessa forma, o rei se tornou em matéria religiosa um estranho a seu povo. Para Hobbes, a única maneira de salvar a autoridade real era desliga-la por completo da religião, tornando-a plenamente soberana em matéria religiosa. $O$ pensador inglês enxerga duas correntes revolucionárias. Uma laica e elitista, advinda da influência das universidades; e outra popular, advinda do puritanismo. A primeira buscava o republicanismo clássico e um passado prestigioso, enquanto a segunda buscava a pureza de um cristianismo primitivo ${ }^{26}$.

Hayek $^{27}$, apesar de afirmar que o reinado dos Stuarts marcou o apogeu do conflito entre parlamento e rei, que culminaria na instituição da liberdade individual, possui uma visão mais economicista. Considera que o conflito surgiu de medidas econômicas não muito estranhas aos dias de hoje, como monopólios industriais instituídos pelo governo, e até uma tentativa de estatização da indústria de carvão. O economista austríaco mostra que a

\footnotetext{
${ }^{24}$ Idem. Ibidem, p. 19.

${ }^{25}$ Idem. Ibidem, p. 38.

${ }^{26}$ Idem. Ibidem, p. 39.

${ }^{27}$ HAYEK. Os Fundamentos da Liberdade, p. 192.
} 
tese defendida por Edward Coke (1552-1634) e outros no período era contrária ao Estatuto dos Monopólios e trazia em seus argumentos a isonomia e necessidade de leis gerais, em concordância com a Magna Carta. Alguns princípios que considera desenvolvidos na época são: (i) legalidade, (ii) irretroatividade das leis, (iii) juízes como simples aplicadores da lei, (iv) supremacia da lei. Outros historiadores discordam dessa tese.

As causas da guerra não eram econômicas, e apenas indiretamente sociais. Mesmo assim, a antiga aristocracia estava mais disposta a favorecer o rei, enquanto o mundo que havia crescido desde a reforma esta disposto a favorecer o parlamento. $\mathrm{O}$ mundo novo estava centrado em Londres, e o velho era mais forte no norte e oeste, mais distantes da órbita da capital ${ }^{28}$.

Hobbes considerava que a guerra civil seria o estado natural da sociedade, assim o princípio no qual a nova ordem se fundaria seria o medo da morte. Como esse era o fundamento da sociedade e do contrato social, a sua violação pelo Estado implicaria no direito de resistência, uma concessão que o autor faz contra o absolutismo. Para o Hobbes, o bem e o mal só teriam sentido na superação do estado de natureza. Essa descrição do estado de natureza destruiu ao mesmo tempo a pretensão do republicanismo clássico, mostrando que a natureza não era boa, e do cristianismo, mostrando que os males não tinham origem no pecado, mas na necessidade ${ }^{29}$.

Para o pensador inglês, o homem no estado de natureza tinha um direito a tudo, que deveria ser renunciado pela coletividade e confiado ao soberano para conseguir a paz. $\mathrm{O}$ fundamento do poder da autoridade, para Hobbes, é o direito do indivíduo, que substi-

${ }^{28}$ TREVELYAN, George Macauley. History of England, Vol. II. New York: Doubleday \& Company, Inc, 1953. p. 185.

${ }^{29}$ MANENT. História intelectual do liberalismo: dez lições, p. 43. tui o bem, marcando assim o começo da linguagem do liberalismo ${ }^{30}$. A unidade do corpo político consiste em todos terem o mesmo representante, o soberano.

Locke é visto pela maioria dos autores como o fundador do liberalismo e ponto inicial de seu estudo. Uma visão menos excludente seria entender que o inglês sistematizou e vulgarizou um pensamento que já estava no ambiente $^{31}$. Este continua a tradição hobbesiana de considerar o estado de natureza como noção chave da reflexão política. Diferencia-se de Hobbes, contudo, ao afirmar que o indivíduo no estado de natureza teria direitos intrínsecos, e o poder político teria a finalidade de proteger esses direitos individuais ${ }^{32}$.

O objetivo da saída do estado de natureza é a conservação de sua propriedade. Os motivos que levam o homem a sair do mesmo são a ausência de uma lei estável com consentimento geral, de um juiz conhecido por todos e imparcial, e do poder para impor decisões da forma devida ${ }^{33}$. Assim, o homem atribui à sociedade, mais precisamente ao legislativo, os poderes que dispunha. Com tal legitimação, o governo deve cumprir os motivos que fizeram o homem sair do estado de natureza e governar tendo em vista a paz, segurança e o bem público do povo.

A propriedade surge como um bem comum que é apropriado com a mistura do trabalho. Quanto à apropriação original, Locke identifica dois atos ilegítimos. Apropriar-se sem deixar uma reserva suficiente para o outro, e estender-se além do que possa gozar, trabalhar e fecundar. $\mathrm{O}$ autor também entende que o cultivo de um terreno aumenta o seu valor e o capital geral da sociedade. Locke

${ }^{30}$ Idem. Ibidem, p. 45.

${ }^{31}$ GRONDONA. Os Pensadores da Liberdade: de John Locke a Robert Nozick, p. 18.

32 MANENT. História intelectual do liberalismo: dez lições, p. 65.

${ }^{33}$ PAIM, Antônio. Evolução histórica do liberalismo. Belo Horizonte. Editora Itatiaia, 1987. p.16. 
rompe com a teoria econômica herdada por Aristóteles que condenava a criação da moeda e a propriedade que excedia os limites do necessário ${ }^{34}$. Para o inglês, aquele que adquire algo com seu trabalho o multiplica em valor, e a ideia de acumular indefinidamente é o produto do consenso humano.

Eis como, na obra do grande pensador inglês, a propriedade e a riqueza tornam-se altamente dignificantes. Em sua raiz encontra um elemento piedoso, devoto, porquanto a propriedade decorre imediatamente da observância de um mandamento divino. A par disto, o ascetismo protestante se entendia então como capaz, por si mesmo, de engendrar a riqueza ${ }^{35}$.

Assim, a origem do poder não é mais mística, natural ou divina. Tomando de Hobbes a lógica contratualista, Locke propõe que o contrato social é feito por homens livres e racionais para fundar um Estado limitado. Cada indivíduo tem um poder soberano e em conjunto decide fundar um Estado com as prerrogativas que lhe outorga.

Locke humaniza a ideia de poder, que se torna secular e moderna. Não há mais elementos religiosos nem despóticos no poder. O que há é o direito de cada homem, que cede livremente certo poder a um governo para que garanta a vida em sociedade ${ }^{36}$.

O direito de propriedade existe dentro do estado de natureza lockeano e é anterior à instituição da sociedade, não depende do consentimento dos outros ou de leis. Como o homem é naturalmente proprietário de sua pessoa, as coisas até então comuns com que mescla seu trabalho se tornam sua legítima propriedade. Os limites do estado de natureza ao direito de propriedade são a apro-

${ }^{34}$ GRONDONA. Os Pensadores da Liberdade: de John Locke a Robert Nozick, p. 23.

${ }^{35}$ PAIM. Evolução histórica do liberalismo, p. 19.

36 GRONDONA. Os Pensadores da Liberdade: de John Locke a Robert Nozick, p. 20. priação de mais do que se pode consumir, e a obrigação de deixar para os outros a oportunidade de se apropriar igualmente de bens na mesma qualidade e quantidade. Em relação ao primeiro limite, sugere que a troca por um equivalente imperecível permitiria a acumulação ilimitada ${ }^{37}$. Como a moeda permite representar quantidades de trabalho, o proprietário legítimo não é mais necessariamente o trabalhador.

Locke está impregnado da ideia puritana de que o homem ganha o céu tendo êxito na terra. Por isso o rico que se enriqueceu por meios legais e corretos suspeita de que vai se salvar. No fundo, mais do que premiar o trabalho, premia-se o mérito. E um trabalho quase religioso. Você foi honesto, trabalhador, ativo, diligente; tem um prêmio nesta terra que antecipa e não anula o prêmio celestial: a propriedade. Os ricos de Locke passam pelo crivo evangélico ${ }^{38}$.

$\mathrm{Na}$ sistematização de Locke, o poder legislativo representava a classe proprietária, que compunha o corpo eleitoral. Este não poderia transferir a delegação de poderes recebidos ou modificar as leis para atender casos particulares. Para executar suas leis, se constitui o poder executivo, que diferente do primeiro, seria permanente. Apesar de não reconhecer como um poder próprio ressalta a importância da independência da magistratura. O terceiro poder para o autor seria o federalista, que cuidaria das relações externas ${ }^{39}$.

Grondona resume a contribuição de Locke para o pensamento liberal em seis ideias: (i) ser livre é estar sujeito à lei, e não a outro indivíduo; (ii) a lei rege governantes e governados por igual, sendo o Estado regido pelo direito; (iii) tais princípios permitem ao homem ser 'melhor' e mais ético; (iv) o direito

${ }^{37}$ MANENT. História intelectual do liberalismo: dez lições, p. 69.

38 GRONDONA. Os Pensadores da Liberdade: de John Locke a Robert Nozick, p. 22.

${ }^{39}$ PAIM. Evolução histórica do liberalismo, p. 20. 
está acima do bem, e não existe um bem geral; (v) não há poder legítimo sem consenso; (vi) e o autobenefício em conformidade com a lei geralmente implica no benefício dos outros ${ }^{40}$.

Fechando os britânicos do período, passamos a outro gigante da tradição liberal, Adam Smith. O escocês vê com grande surpresa a prosperidade e a existência de um processo de enriquecimento, pois o habitual na história, até então, era a estagnação. Vale lembrar que este não era um economista por formação, mas sim um moralista. Com esta formação, reconhece a existência de três virtudes. A prudência, que faz com que se busque o próprio bem; a justiça, que proíbe prejudicar o próximo; e a benevolência que é o desejo de favorecer o próximo. Ao Estado apenas caberia a justiça. Essa herança moralista influenciaria muitas ideias de Smith.

Smith tem ao mesmo tempo um juízo moral severíssimo e um juízo econômico favorável ao sistema de seu tempo. Apesar de julgar como moralmente negativos vários aspectos sociais, considera que é possível viver bem apesar destes. A mão invisível para o escocês é uma patologia, algo que ocorre e ele aceita, mas não um princípio para a bondade e moral se basearem.

Smith rompe a noção de economia como jogo de soma zero e defende que o comércio e a troca enriquecem ambos os participantes. Quanto a organização do Estado, Grondona mostra outro lado do escocês.

O que interessa frisar é que o Estado que Smith imagina não é mínimo nem irracionalmente grande. O princípio seria: o Estado mínimo é o ideal, mas devemos estar dispostos a permitir um Estado maior que o mínimo quando graves circunstâncias o aconselhem. O Estado é um mal menor; quando um grave problema não pode ser corrigido pela sociedade, o Estado deve atuar ${ }^{41}$.

40 GRONDONA. Os Pensadores da Liberdade: de John Locke a Robert Nozick, p. 28-30.

41 GRONDONA. Os Pensadores da Liberdade: de John Locke a Robert Nozick, p. 50.
Enumerando as contribuições de Smith para o liberalismo, Grondona organiza os seguintes itens: (i) a ideia de que há uma ordem natural no Universo; (ii) a análise das virtudes, com a conclusão que há dois níveis morais, um mínimo que é juridicamente exigível, consistindo em não fazer o mal, e outro superior, que não é juridicamente exigível, mas desejável; (iii) A moderação do amor a si mesmo; (iv) a inclinação pelo pobre, para que ele trabalhe, cresça e progrida proporcionalmente ao mérito até deixar de ser pobre; $(\mathrm{v})$ a distinção entre ser e dever ser, resultados e intenções, com ênfase na importância daqueles; (vi) a presença de uma visão positiva e otimista sobre a vida; (vii) a visão da competição como um processo de cooperação que leva a própria superação; (viii) e a ideia de uma fórmula para o progresso envolvendo segurança jurídica, livre comércio e competição ${ }^{42}$.

Do outro lado da Mancha, o pensamento liberal também floresce e oferece contribuições. Montesquieu mantém as intenções políticas de Locke, porém adota linguagem e meios diferentes. O francês abandona os conceitos de direitos absolutos e soberania como entendidos por Locke. Sua doutrina não se fundamenta na análise da condição original do homem ou das bases de legitimidade política, mas da interpretação de uma experiência política, a inglesa ${ }^{43}$.

Diferente de Locke, o interesse de Montesquieu não é a origem do poder, mas seu exercício e funcionamento. A sua solução para evitar o abuso do poder é opô-lo ao próprio poder. Montesquieu se convence de que é possível harmonizar os desejos do homem e as necessidades do corpo político pela distribuição de poderes. Vale notar que, famoso pela ideia de poderes entre legislativo, executivo e judiciário, o francês considera este terceiro como de menor importância. O legislativo contem, para o barão, a vontade geral

\footnotetext{
${ }^{42}$ Idem. Ibidem, p. 51-60.

${ }^{43}$ MANENT. História intelectual do liberalismo: dez lições, p. 85.
} 
do Estado, e o executivo, a execução desta ${ }^{44}$. Acredita que o equilíbrio da divisão de poderes aconteça por meio de partidos.

Essa tradição inglesa influenciaria também o outro lado do Atlântico no processo da revolução americana, primeiro na Independência (1776) e posteriormente na Constituição (1787). A obra principal desse processo foi $O$ Federalista. Esta trata menos sobre direitos e garantias da liberdade e mais sobre a organização federal. O objetivo dos autores é harmonizar a consolidação do Estado com a necessidade de limitá-lo ${ }^{45}$. As grandes influências para eles são o sistema inglês e o pensador Montesquieu.

Falando sobre a contribuição americana para a causa da liberdade, Hayek afirma que o seu processo de independência tinha caráter mais conservador do que revolucionário. O objetivo era preservar as liberdades tradicionais inglesas contra a opressão do parlamento ${ }^{46}$. A constituição buscava limitar os poderes, em especial o legislativo, criando um governo de leis e não de homens.

Publius [o federalista] só pede ao Estado que permaneça, que se mantenha quase sem mudanças. Pois é dentro dele que se realizará o dinamismo. Um Estado inconstante que parece dinâmico no fundo é reacionário ${ }^{47}$.

O Federalista defende a divisão do poder verticalmente entre a ordem nacional e as locais, e horizontalmente, num congresso e presidente eleitos pelo povo. Os autores da obra entendiam que os freios e contrapesos não poderiam ser apenas horizontais, divididos entre os três poderes do governo federal. Sem um sistema vertical, os três poderes federais poderiam simplesmente se unir para pri-

\footnotetext{
${ }^{44}$ Idem. Ibidem, p. 88.

45 GRONDONA. Os Pensadores da Liberdade: de John Locke a Robert Nozick, p. 61.

${ }^{46}$ HAYEK. Os Fundamentos da Liberdade, p. 207.

47 GRONDONA. Os Pensadores da Liberdade: de John Locke a Robert Nozick, p. 63.
}

var os Estados de seus direitos ${ }^{48}$. Inicialmente houve uma oposição à inclusão de uma declaração de direitos na constituição, porque seria redundante declarar um direito a algo que já não estava na competência do Estado de legislar ${ }^{49}$.

Para os habitantes da colônia, liberdade significava que o governo deveria ter poderes apenas para ações explicitamente previstas por lei, a fim de que ninguém pudesse estar investido de poder ilimitado. ${ }^{50}$

Grondona lista as seguintes contribuições principais dos autores de $O$ Federalista: (i) a distinção entre dois conservadorismos: um que busca conservar as instituições para manter um quadro jurídico estável, e outro que busca conservar as estruturas sociais; (ii) a diferença entre o liberalismo como tradição concreta e como esquema intelectual; (iii) o desenvolvimento como uma sequência lógica entre homens moralmente independentes, seu posterior desejo por uma estrutura político-institucional e finalmente, a prosperidade; (iv) e a defesa de um exército pequeno e profissional em oposição aos exércitos permanentes que provocariam tensão entre o poder militar e o poder civil ${ }^{51}$.

A influência da constituição americana foi marcante para todo o pensamento político-jurídico no mundo graças ao desenvolvimento do controle de constitucionalidade. Este mecanismo, para Hayek, veio como forma de salvaguardar as limitações do poder expressas na constituição e evitar um legislativo ilimitado, como acredita ocorrer na Inglaterra. O controle de constitucionalidade passou por diversas fases, até chegar

\footnotetext{
${ }^{48}$ WOODS, Thomas E. Jr. Nullification: How to resist federal tyranny in the $21^{\text {st }}$ century. Washington D.C.: Regnery Publishing, Inc, 2010. p. 4.

${ }^{49}$ HAYEK. Os Fundamentos da Liberdade, p. 219.

${ }^{50}$ Idem. Ibidem, p. 208.

51 GRONDONA. Os Pensadores da Liberdade: de John Locke a Robert Nozick, p. 68-71.
} 
ao final do século XIX como um controle de razoabilidade das leis ${ }^{52}$.

$\mathrm{Na}$ França, a tentativa de criação de um Estado de direito coincidiu com o avanço do conceito de soberania popular, minando os fundamentos da restrição aos poderes estatais ${ }^{53}$. Antes de passar para a análise das consequências da Revolução Francesa para o pensamento liberal, vale a pena analisar o autor que mais influenciou o movimento. Rousseau dialoga principalmente com Hobbes, ambos enxergam o problema político europeu como causado pela rivalidade e distinção entre o poder religioso e político. O francês, contudo, critica além da superestrutura do Estado absolutista, a infraestrutura da sociedade civil individualista ${ }^{54}$.

O motor do contrato social em Rousseau está no entendimento de que a sociedade é corrupta e o homem está infeliz enquanto dividido. O homem no estado de natureza estava feliz e bom porque é uno, ele basta a si mesmo. O objetivo da boa política e de conceitos como vontade geral é estabelecer essa unidade. Manent ${ }^{55}$ considera tal proposta artificial, já que busca modificar a natureza humana e transformar o indivíduo. A propriedade para Rousseau é vista de forma ambígua, ora sendo considerada como sagrada e ora como a usurpação original. Para o autor, diferentemente de Locke, o trabalho não pode fundamentar o direito de propriedade, de modo que ela é garantida pela lei, na saída do estado de natureza.

Diferentemente do indivíduo liberal que não é interiormente livre, o de Rousseau é não apenas interiormente livre, mas também imbuído de um sentimento de autonomia. Essa nova liberdade é uma ameaça para as sociedades liberais, pois busca na

\footnotetext{
${ }^{52}$ HAYEK. Os Fundamentos da Liberdade, p. 225.

${ }^{53}$ Idem. Ibidem, p. 232.

${ }^{54}$ MANENT. História intelectual do liberalismo: dez lições, p. 106.

${ }^{55}$ Idem. Ibidem, p. 114.
}

revolução o ato para lhe dar uma motivação própria.

A Revolução Francesa obedeceria, em seu próprio desenrolar, ao ritmo do pensamento de Rousseau. Surgiria em 1789 com o intuito de enfim proteger adequadamente a segurança e a propriedade dos indivíduos; voltar-se-ia, em 1793, contra essa segurança e essa propriedade, para conseguir a unidade absoluta do novo corpo político; em 9 de Termidor, renunciaria a esse esforço "contra a natureza", que tendia a anular seu próprio fundamento, e se reconciliaria com a propriedade e sua desigualdade $\mathrm{e}^{56}$.

Kant também contribuiu com grandes inovações para o pensamento político e liberal. O Estado, para o pensador prussiano, não tem fins próprios nem dirige os súditos para fins específicos, mas unicamente os vigia para impedir que, na busca de seus próprios fins, cheguem a conflitos ${ }^{57}$.

A forma de governo boa ou má, para Kant, não depende das pessoas que detém poder, mas de sua forma orgânica. A boa forma de governo seria a republicana, que para o autor não se opõe à monárquica, mas sim ao despotismo. O sistema republicano liberal, que considera a melhor forma de governo, está configurado na perfeita repartição dos poderes dentro do Estado ${ }^{58}$. Neste sentido podemos comparar com a definição de tirania para Locke, que diferente dos clássicos, não é agir em função do bem próprio, mas sim o exercício de um poder para além do direito ${ }^{59}$.

O prussiano foi responsável por expor os fundamentos filosóficos do liberalismo. Grondona ${ }^{60}$ enumera sua importância nos seguintes ensinamentos: (i) o conceito de bem é

\footnotetext{
${ }^{56}$ Idem. Ibidem, p. 119.

${ }^{57}$ PAIM. Evolução histórica do liberalismo, p. 25.

${ }^{58}$ Idem. Ibidem, p. 27.

${ }^{59}$ GRONDONA. Os Pensadores da Liberdade: de John Locke a Robert Nozick, p. 27.

${ }^{60}$ Idem. Ibidem, p. 81-83.
} 
definido pela máxima que preside a ação e pela lei que preside a máxima; (ii) a defesa da soberania dos seres racionais; (iii) o entendimento que a moralidade está acima da felicidade e que esta não é um objetivo, mas uma consequência; (iv) a pessoa é um fim em si mesmo e não pode ser instrumentalizada para fins alheios; (v) a existência de um imperativo prático que determina o tratamento de todo homem como um fim em si mesmo; (vi) a ideia de que o ser racional é legislador universal; (vii) e o conceito de liberdade como autonomia, a capacidade de ditar a própria lei.

Apesar de existirem poucos autores liberais modernos na Prússia, Hayek vê uma grande contribuição prussiana para o Estado de Direito, na forma do controle judicial sobre o poder administrativo ${ }^{61}$. A independência dos tribunais administrativos foi fundamental para garantir que não haverá interferência nas suas decisões e que estes vão seguir normas gerais e não realizar a vontade do governo.

Para Manent, o ciclo do liberalismo como resolução do problema teológico-político teve fim em Rousseau e na Revolução Francesa. O segundo liberalismo, da primeira metade do século XIX, buscaria absorver o choque desses acontecimentos. Apenas Edmund Burke (1729-1797), dos grandes liberais pós Revolução Francesa, realizou a condenação desta. Tal fato é estranho para o autor francês, que considera que as liberdades foram mais bem preservadas no antigo regime que durante a revolução ou o império ${ }^{62}$. O novo liberalismo via a história como uma força que substituía o estado de natureza, e a igualdade como um novo objetivo a ser buscado.

O liberalismo doutrinário é a versão francesa do liberalismo inglês, e seus pensadores elaboraram questões teóricas de grande relevância. Além de Benjamin Constant,

\footnotetext{
${ }^{61}$ HAYEK. Os Fundamentos da Liberdade, p. 238.

${ }^{62}$ MANENT. História intelectual do liberalismo: dez lições, p. 124.
}

compõe o grupo François Guizot (1787-1874), Pierre Paul Royer-Collard (1763-1845), Victor de Broglie (1785-1870), Charles de Rémusat (1797-1875), Hercule de Serre (1776-1824) e Camille Jordan (1771-1821). Na monarquia de Luís Felipe (1773-1850), os liberais doutrinários chegariam ao poder e virariam um liberalismo de governo. Os liberais doutrinários discordavam que a Revolução Francesa apesar de ter pecado pelo excesso, teria princípios certos. Eles se opunham tanto à doutrina revolucionária quanto à contrarrevolucionária, na temática da soberania, criticavam a soberania real dos ultras e a soberania popular revolucionária, para defenderem que ela pertence à razão humana ${ }^{63}$.

Benjamin Constant foi ao mesmo tempo defensor da revolução contra o antigo regime e crítico severo do espírito da política revolucionária, e depois, da imperial. O autor mantém essa mesma dualidade quando defende a soberania popular ao mesmo tempo que critica seus excessos. A sua explicação para essa defesa está em seu entendimento do conceito, para o autor, a soberania tem valor mais negativo que positivo, significando que nenhum grupo de indivíduos tem o direito de submeter a generalidade dos cidadãos à sua vontade particular ${ }^{64}$.

Constant vê os males da revolução como fruto da tentativa de realizar a liberdade dos antigos na França moderna. O homem moderno possuía uma vida diferente da do antigo, encontrava seus prazeres na vida privada, de modo que a engenharia social de aplicar a política antiga na sociedade moderna faria os homens sofrerem terrivelmente por viverem em contradição ${ }^{65}$.

Numa época de hostilidade com a religião, Benjamin Constant teve a coragem de defender o sentimento religioso sem cair na

\footnotetext{
${ }^{63}$ PAIM. Evolução histórica do liberalismo, p. 42.

${ }^{64}$ MANENT. História intelectual do liberalismo: dez lições, p. 132.

${ }^{65}$ Idem. Ibidem, p. 136.
} 
tentação reacionária de pregar pela volta da vinculação entre Igreja e Estado. Foi também defensor do poder moderador, exercendo influência profunda no imperador D. Pedro I $(1798-1834)^{66}$.

François Guizot marcou o liberalismo por procurar torná-lo governante e propositivo. Para o ministro francês, o desenvolvimento político moderno leva ao crescimento simultâneo da ação do poder sobre a sociedade e da influência desta sobre aquele. Dessa forma, queria ensinar o governo a não considerar a sociedade como inimiga, e a oposição liberal a não considerar o poder como um inimigo $^{67}$. Guizot rompe com a tradição liberal clássica de ver o poder político como artificial, para considerar que este é natural no homem. O poder como tal seria uma coisa boa, a expressão da superioridade natural.

Desde os meados do século XIX, este [liberalismo] não é apenas a experiência, as instituições e a doutrina inglesa mas esse conjunto acrescido da meditação de Kant e dos doutrinários. De modo que o processo de democratização da ideia liberal na segunda metade da centúria, de que a Inglaterra é também o arquétipo, já não se inspira apenas na atividade teórica local mas leva em conta a contribuição continental ${ }^{68}$.

Esses autores doutrinários marcaram a contraofensiva liberal no reinado Orléans. Com o exílio de Guizot, a queda do rei e a proclamação da Segunda República, o liberalismo francês voltaria à defensiva. Nesse contexto, Tocqueville pode ser considerado um pensador do liberalismo na defensiva, sobre ataque, no século XIX, tanto dos revolucionários, quanto dos reacionários.

Tocqueville estudou a democracia e a igualdade. Para o autor, a grande diferença entre a França e os EUA estava no fato de

\footnotetext{
${ }^{66}$ PAIM. Evolução histórica do liberalismo, p. 37.

${ }^{67}$ MANENT. História intelectual do liberalismo: dez lições, p. 146.

${ }^{68}$ PAIM. Evolução histórica do liberalismo, p. 33.
}

que neste as pessoas nasciam iguais, ao invés de vir a sê-lo. Assim, a igualdade democrática havia criado instituições políticas que lhe eram adequadas e que já haviam provado sua flexibilidade e estabilidade. A democracia para o autor seria um estado social, definido pela igualdade de condições, e não um conjunto de instituições políticas ${ }^{69}$. No mesmo entendimento, Grondona também vê a democracia para o pensador francês mais como um processo social de igualação das condições do que uma forma de governo ${ }^{70}$.

Alexis de Tocqueville, ao mesmo tempo em que reconhecia o ímpeto das tendências igualitárias, temia a emergência de uma sociedade de massas, manipulada por uma classe de ideólogos e burocratas, e governada por um Estado leviatã ${ }^{71}$. Para o autor, a democracia precisa realizar a exclusão da aristocracia e das desigualdades de condição, ela busca algo que não pertence nem à ordem civil nem à ordem política, trata-se de um tipo particular de relação entre os homens que paradoxalmente se define pela ausência de relações ${ }^{72}$.

Assim, o espetáculo da democracia revelou a Tocqueville que aquilo que o liberalismo considerava a hipótese, o dado ou o pressuposto da ordem política legítima tinha de ser buscado, criado ou construído. $\mathrm{O}$ estado de natureza não era o começo da história política do homem, mas antes seu término, ou, pelo menos, seu horizonte. $\mathrm{O}$ projeto liberal, por querer fundamentar-se na igualdade natural, inaugurava, portanto, uma história: a história dos esforços e dos progressos do homem para estabelecer artificialmente, graças a uma soberania que não existia na natureza, a igualdade natural a partir da qual pudesse construir, de maneira plenamente racional ou consciente, a or-

${ }^{69}$ MANENT. História intelectual do liberalismo: dez lições, p. 159.

${ }^{70}$ GRONDONA. Os Pensadores da Liberdade: de John Locke a Robert Nozick, p. 87.

${ }^{71}$ PAIM. Evolução histórica do liberalismo, p. 45.

${ }^{72}$ MANENT. História intelectual do liberalismo: dez lições, p. 161. 
dem política legítima. Não deixando a natureza de produzir desigualdades, influências e dependências, esse primeiro momento era permanente: era a tônica da democracia, constituía a natureza dela, já que era a condição básica de todas as convenções e dava ao homem democrático o sentimento de estar vivendo na história, pois o fazia viver dentro de um projeto do qual esse homem era, ao mesmo tempo, o senhor soberano e a matéria dúctil ${ }^{73}$.

Assim, a tradição liberal fecha o século XIX voltando para a Inglaterra influenciada pelo movimento democrático francês. O sistema representativo inglês se consolidou no Século XIX com as reformas eleitorais. O século anterior viu o ajuste do relacionamento entre executivo e o parlamento, o papel da monarquia, a estruturação dos partidos políticos e as liberdades de imprensa e religião. Em 1832 os liberais aprovam uma reforma eleitoral triplicando o eleitorado e aumentando a representação das cidades. Nas décadas seguintes conseguiriam derrubar a lei dos cereais e outras medidas protecionistas, além de legalizar sindicatos, introduzir o voto secreto, aumentar o sufrágio e a representação do eleitor. Tais reformas foram feitas de forma gradual, evitando o radicalismo dos cartistas e não caindo nas tentações do democratismo, mantendo as bases para a democratização do liberalismo e manutenção do estado democrático de direito $^{74}$.

Hayek aponta que o século XVIII se marcou pela consolidação dos princípios liberais na Inglaterra. Considera, contudo, que a separação de poderes foi progressivamente se perdendo enquanto se desenvolvia o governo de gabinete. Posteriormente aponta que mais um princípio foi perdido quando o parlamento reivindicou poder ilimitado. Essa contribuição inglesa começa a decair no século XIX, quando a influência das tendências raciona-

\footnotetext{
${ }^{73}$ Idem. Ibidem, p. 171.

${ }^{74}$ PAIM. Evolução histórica do liberalismo, p. 63-67.
}

listas da tradição francesa e o novo utilitarismo de Bentham introduziram algo novo na Inglaterra. O desejo de reformular a totalidade das leis e instituições do país com base em princípios racionalistas ${ }^{75}$.

Nesse contexto, John Stuart Mill reconhece que o perigo da tirania da opinião majoritária é tão grande quanto o perigo da tirania do rei. A liberdade para o autor francês consiste no autogoverno e na defesa da soberania individual, e a justiça na sua concepção é a parte do comportamento com terceiros passível de ser exigida pelo poder público ${ }^{76}$.

O século XX começa com grande influência do pensamento germânico no liberalismo. Max Weber (1864-1920), assim como Tocqueville, é um liberal na defensiva, procurando questionar os valores antiliberais do nacionalismo e do marxismo. Weber inverte a tese de Karl Marx (1818-1883) de que o econômico é a base dos fenômenos espirituais para defender que a aparição do protestantismo está na origem do desenvolvimento econômico.

Grondona resume as principais teses de Weber em cinco: (i) a negação do monocausalismo de Marx e a defesa da interação entre espiritual e econômico; (ii) o desencanto por valores, na tradição do liberalismo defensivo; (iii) A percepção no protestantismo dos valores que mudam a atitude mística e resultam na riqueza; (iv) a visão do desenvolvimento como uma mudança de ênfase moral, uma ética econômica; (v) a defesa de que a revolução chamada de liberal culmina numa mudança econômica, mas começa por uma mudança nos espíritos ${ }^{77}$.

Se Weber foi um liberal na defensiva, Karl Popper (1902-1994) marca a contraofensiva liberal. Com base nos seus conceitos de sociedade aberta e tribal, afirma que a transição desta para aquela gera angústia e inse-

\footnotetext{
${ }^{75}$ HAYEK. Os Fundamentos da Liberdade, p. 203.

76 GRONDONA. Os Pensadores da Liberdade: de John Locke a Robert Nozick, p. 102.

${ }^{77}$ Idem. Ibidem, p. 121.
} 
gurança. O totalitarismo em Popper é fruto do historicismo resultante dos que querem controlar a mudança, pois enxergam que a história é previsível. Essa ideologia traz como consequência a ideia de que se pode construir uma sociedade. O liberal, por outro lado, vê a história como resultado da interação de milhares de vontades, aberta e multidirecional.

Finalizaremos esse capítulo com a escola de Viena e Ludwig von Mises (1881-1973), professor de Hayek que o influenciou profundamente. Para Mises, a evolução do pensamento econômico se deu com a passagem da catalática para a praxiologia. A primeira foi herança dos filósofos, e usava um vocabulário que para o economista austríaco tinha sentido de devaneio e ilusão. A segunda, como a escola austríaca se deu conta, consiste na ciência que regula toda a ação humana, econômica ou não econômica. Para completar a transição de uma para outra, a economia deve abandonar a busca dos clássicos pela objetividade ${ }^{78}$.

Agir, para Von Mises, é optar. Constantemente opto de maneira livre; a liberdade é a capacidade que tenho de me autogovernar $^{79}$.

Para o mentor de Hayek, a competição não é uma ideologia dos ricos, pois estes tendem a adotar uma postura mais protecionista, evitando novos competidores. A riqueza para o austríaco não é a que já existe, mas a que vai existir e pode ser criada. Assim, os mais beneficiados pela competição são aqueles que não tem uma posição já formada.

Mises critica a fé dos liberais clássicos na razão humana, que acreditavam que deixados em liberdade iriam se superar moralmente. Considera a racionalidade presumida como um conceito que leva à democracia totalitária. Apesar de ser utilitarista, difere de Mill por adotar um relativismo. Para o austríaco, cada homem busca o que entende melhor num

\footnotetext{
${ }^{78}$ Idem. Ibidem, p. 130.

${ }^{79}$ Idem. Ibidem, p. 132.
}

dado momento, enquanto para o inglês a felicidade consiste nos prazeres mais nobres ${ }^{80}$.

Esse breve panorama das ideias liberais não busca ser exaustivo ou final; o liberalismo, por ser um movimento aberto, abarca diversas divisões e autores. No pensamento latino-americano vale citar Juan Bautista Alberdi (1810-1884), Domingo Faustino Sarmiento (1811-1888), Mariano Grondona. No Brasil, longe de ser uma tradição ausente, vemos diversos autores antigos e modernos. Citamos alguns: Visconde de Cairu (1756-1835), José Guilherme Merquior, Roberto Campos (19172001), Ubiratan Borges de Macedo, Antônio Paim, Og Leme (1923-2004) e Ubiratan Jorge Iorio.

Por fim, vale citar três intelectuais liberais contemporâneos aos trabalhos de Hayek. Robert Nozick (1938-2002), que marca a contraofensiva liberal na filosofia política da segunda metade do último século. John Rawls (1921-2002), que mesmo não sendo usualmente considerado um liberal, pode ser enquadrado nesta escola. Para Grondona ${ }^{81}$, Rawls apesar de todas as concessões para a igualdade material e a intervenção estatal permanece defendendo a liberdade e competição como princípios. Rawls busca criar uma teria política que permita a convivência social de um país onde metade é composta por liberais e a outra por socialdemocratas. Por fim, Murray Newton Rothbard (1926-1995), que levaria a contraofensiva liberal a outro patamar, levando a propriedade privada e a defesa da liberdade para suas últimas consequências. cos

\footnotetext{
${ }^{80}$ Idem. Ibidem, p. 137.

${ }^{81}$ Idem. Ibidem, p. 154.
} 